\title{
Validation of microsatellite markers for cytotype discrimination in the model grass Brachypodium distachyon
}

\author{
Patricia Giraldo, Marta Rodríguez-Quijano, José F. Vázquez, José M. Carrillo, and \\ Elena Benavente
}

\begin{abstract}
Brachypodium distachyon (L.) P. Beauv. $(2 n=2 x=10)$ is a small annual grass species where the existence of three different cytotypes $(10,20$, and 30 chromosomes) has long been regarded as a case of autopolyploid series with $x=5$. However, it has been demonstrated that the cytotypes assumed to be polyploids represent two separate Brachypodium species recently named as Brachypodium stacei $(2 n=2 x=20)$ and Brachypodium hybridum $(2 n=4 x=30)$. The aim of this study was to find a PCR-based alternative approach that could replace standard cytotyping methods (i.e., chromosome counting and flow cytometry) to characterize each of the three Brachypodium species. We have analyzed with four microsatellite (SSR) markers 83 B. distachyon-type lines from varied locations in Spain, including the Balearic and Canary Islands. Within this set of lines, 64, 4, and 15 had 10, 20, and 30 chromosomes, respectively. The surveyed markers produced cytotype-specific SSR profiles. So, a single amplification product was generated in the diploid samples, with nonoverlapping allelic ranges between the $2 n=10$ and $2 n=20$ cytotypes, whereas two bands, one in the size range of each of the diploid cytotypes, were amplified in the $2 n=30$ lines. Furthermore, the remarkable size difference obtained with the SSR ALB165 allowed the identification of the Brachypodium species by simple agarose gel electrophoresis.

Key words: Brachypodium distachyon, B. stacei, B. hybridum, cytotype-specific markers, SSR analysis.
\end{abstract}

Résumé : Le Brachypodium distachyon (L.) P. Beauv. $(2 n=2 x=10)$ est une petite graminée annuelle chez laquelle l'existence de trois cytotypes différents (à 10, 20 ou 30 chromosomes) a longtemps été considérée comme une série autopolyploïde avec $x=5$. Cependant, il a été démontré que les cytotypes qui étaient présumés polyploïdes représentent en fait deux espèces distinctes du genre Brachypodium récemment nommées Brachypodium stacei $(2 n=2 x=20)$ et Brachypodium hybridum $(2 n=4 x=30)$. Le but de ce travail était de trouver une approche PCR permettant de remplacer les méthodes cytologiques (décomptes chromosomiques, cytométrie en flux) pour caractériser les trois espèces de Brachypodium. Les auteurs ont analysé 83 lignées de type $B$. distachyon provenant de différents sites en Espagne, incluant les Îles Baléares et Canaries, au moyen de quatre marqueurs microsatellites (SSR). Au sein de cette collection, 64, 4 et 15 lignées présentaient respectivement 10, 20 et 30 chromosomes. Les marqueurs examinés ont produit des profils spécifiques des cytotypes. Ainsi, un seul amplicon a été obtenu chez les échantillons diploïdes et les séries alléliques ne chevauchaient pas entre les cytotypes à $2 n=$ 10 et $2 n=20$, tandis que deux amplicons ont été obtenus chez les lignées à $2 n=30$, chacun de ces amplicons logeant à l'intérieur des séries alléliques observées chez les cytotypes diploïdes. De plus, la différence de taille remarquable observée entre les amplicons du SSR ALB165 permettait l'identification des espèces de Brachypodium sur un simple gel d'agarose.

Mots-clés : Brachypodium distachyon, B. stacei, B. hybridum, marqueurs spécifiques du cytotype, analyse SSR.

[Traduit par la Rédaction]

\section{Introduction}

The annual grass Brachypodium distachyon (L.) P. Beauv. (Pooideae) is increasingly becoming recognized as the most suitable model organism for temperate cereal crop research. Since the initial proposal of Draper et al. (2001), the development of analytical tools and genomic resources has been extraordinarily rapid and fruitful (Ozdemir et al. 2008; for recent updates see Mur et al. 2011; Vain 2011). Availability of a wide genetic diversity is also required to approach the molecular dissection of most agronomically relevant traits. Consequently, a number of studies have been focused on the characterization of $B$. distachyon natural accessions and derived lines (Filiz et al. 2009; Vogel et al. 2009; Mur et al. 2011; Catalán et al. 2012; Manzaneda et al. 2012). Germ-

Received 29 December 2011. Accepted 8 June 2012. Published at www.nrcresearchpress.com/gen on 12 July 2012.

Corresponding Editor: G. Jenkins.

P. Giraldo, M. Rodríguez-Quijano, J.F. Vázquez, J.M. Carrillo, and E. Benavente. Departamento de Biotecnología (Genética), Escuela Técnica Superior de Ingenieros Agrónomos, Universidad Politécnica de Madrid, 28040-Madrid, Spain.

Corresponding author: Patricia Giraldo (patricia.giraldo@upm.es). 
plasm resources, mainly originating from Turkey and Spain, are currently available to the scientific community. However, taking into account the ample spatial distribution of this wild grass (Garvin et al. 2008; Catalán et al. 2012), enlarging the Brachypodium gene pool remains as a feasible and valuable research objective.

Brachypodium distachyon $(2 n=2 x=10)$ has recently been taxonomically separated from two other Brachypodium species: the diploid Brachypodium stacei $(2 n=20)$ and the allotetraploid Brachypodium hybridum $(2 n=30)$ (Catalán et al. 2012). These three species had been earlier collected and catalogued under the same botanical name, B. distachyon, evidencing their great similarity for most external traits. The existence of distinct cytotypes, with $2 n$ values of 10,20 , and 30 chromosomes (Robertson 1981), was assumed to be a case of an autopolyploid series with $x=5$. Nonetheless, solid experimental evidences support that $B$. hybridum derives from B. distachyon and B. stacei (Hasterok et al. 2004, 2006; Idziak et al. 2011; Catalán et al. 2012). Under the framework established by Catalán and co-workers, all newly collected or yet uncharacterized B. distachyon-type accession must be unambiguously assigned to the right species to be valuable for further research. This is especially important to guarantee that any germplasm, genetic, or genomic tool eventually developed corresponds to the true model species, B. distachyon $(2 n=10)$.

Catalán et al. (2012) have described significant phenotypic differences among the three cytotypes (i.e., species) for several quantitative characters. Nonetheless, the overlapping ranges reported for some of them, as well as the uncertainty about their actual level of intraspecific natural variation, make it risky to exclusively use morphometric traits for taxomomic assignment of any accession or line. Currently, chromosome counting and flow cytometry are among the best alternatives. The former provides reliable species identification by conducting direct cytotyping. However, flow cytometry sharply distinguishes the allotetraploid $B$. hybridum from the others (2C genome size values ranging from $1.3 \mathrm{pg}$ (e.g., Draper et al. 2001) to $1.6 \mathrm{pg}$ (Manzaneda et al. 2012)), but could not discriminate between $B$. distachyon, with 2C DNA content estimations from $0.42 \mathrm{pg}$ (Draper et al. 2001) to 0.9 pg (Manzaneda et al. 2012), and B. stacei (2C DNA value of 0.56 pg in Catalán et al. 2012). Nevertheless, the main limitation of these two methods is that both are time-consuming and require expertise or equipment that are sometimes unavailable.

Our study aimed to validate the utility of a widely used PCR-based approach for species identification of annual Brachypodium specimens. For this, we have conducted SSR (single sequence repeats) analysis of $B$. distachyon, B. stacei, and $B$. hybridum lines whose cytotypes had been earlier confirmed by direct chromosome count.

\section{Materials and methods}

\section{Plant material}

The study has been carried out on the collection of Brachypodium lines held at UPM (Universidad Politécnica de Madrid, Spain). It is composed of 64 lines of B. distachyon
$(2 n=10), 2$ lines of B. stacei $(2 n=20)$, and 12 lines of $B$. hybridum $(2 n=30)$ that derive from single seed descent of $B$. distachyon-type specimens collected by our group in about 70 locations across a wide area of the Iberian Peninsula (latitude: $36^{\circ} 44^{\prime} \mathrm{N}$ to $42^{\circ} 30^{\prime} \mathrm{N}$; longitude: $0^{\circ} 09^{\prime} \mathrm{E}$ to $6^{\circ} 40^{\prime} \mathrm{W}$ ) and the Balearic Islands (Menorca). Five lines from the germplasm bank of the National Centre of Plant Genetic Resources of Spain (CRF-INIA) have also been analyzed. These lines were established from individual plants collected in 1995 in the Canary Islands by a Spanish-Japanese consortium. Two of them correspond to the $2 n=20$ cytotype, while the remaining three lines correspond to the $2 n=30$ cytotype. Figure 1 shows the location of collection sites for all the Spanish lines examined; detailed information regarding their geographical origin is given as supplementary material (Table $\mathrm{S} 1)^{1}$. The type specimens of $B$. distachyon (line $\mathrm{Bd} 21$; originating from Irak), B. stacei (line ABR114; from Formentera, Balearic Islands, Spain), and B. hybridum (line ABR113; from Lisbon, Portugal) have also been included in the study.

\section{Microsatellite (SSR) analyses}

For the SSR analysis of the Brachypodium lines, DNA was extracted from leaf samples using the Ultra Clean Plant DNA Isolation kit (MOBIO), according to manufacturer's instructions. PCR was carried out in a $20 \mu \mathrm{L}$ reaction volume containing $2 \mathrm{mmol} / \mathrm{L} \mathrm{MgCl}_{2}, 200 \mu \mathrm{mol} / \mathrm{L} \mathrm{dNTPs}, 5 \mu \mathrm{mol} / \mathrm{L}$ of each primer, $100 \mathrm{ng}$ of template DNA, and 1U of Taq DNA Polymerase (Biotools) using a MyCycler thermocycler (BioRad). PCR cycling conditions were as follows: 2 min at $94{ }^{\circ} \mathrm{C}$, followed by 40 cycles of $1 \mathrm{~min}$ at $94{ }^{\circ} \mathrm{C}, 1 \mathrm{~min}$ at annealing temperature $\left(52-56{ }^{\circ} \mathrm{C}\right)$ of each primer pair, $1 \mathrm{~min}$ at $72{ }^{\circ} \mathrm{C}$, and final extension of $10 \mathrm{~min}$ at $72{ }^{\circ} \mathrm{C}$. The PCR products with different fluorescent labels were mixed with Hi Di formamide and Liz internal size standard, denatured at $95{ }^{\circ} \mathrm{C}$ for $5 \mathrm{~min}$, and genotyped on a ABI PRISM 3100 DNA analyzer (Applied Biosystems, USA). Allele sizing for different DNA fragments was carried out by GeneMarker software (SoftGenetics, LLC, USA). In the case of ABL165 marker, amplification products were also analyzed in 2.5\% Seakem LE agarose gels (Lonza) staining with GelRed (Biotium).

\section{Results and discussion}

An initial set of $B$. distachyon-type accessions was profiled with 15 microsatellites (SSRs) selected based on their genomic distribution and polymorphism level when data were available (Garvin et al. 2008; Vogel et al. 2009). Five of them (ALB165, ALB311, BdSSR207, BdSSR330, and R2-3$\mathrm{ABI}$ ) behaved as potential species-specific markers. BdSSR207, which maps very close to R2-3-ABI, was finally discarded as it failed to show a robust profile. The remaining four SSR markers were tested in a total of $64 \mathrm{~B}$. distachyon $(2 n=2 x=10), 4$ B. stacei $(2 n=2 x=20)$, and 15 B. hybridum $(2 n=4 x=30)$ Spanish lines established at the UPM and in the reference lines of the three species, namely, Bd21, ABR114, and ABR113. See supplementary Table S2 for further description of the microsatellite marker loci used.

Invariably, amplification of ALB165, ALB311, BD330,

\footnotetext{
${ }^{1}$ Supplementary data are available with the article through the journal Web site (http://nrcresearchpress.com/doi/suppl/10.1139/g2012-039).
} 
Fig. 1. Location of collection sites of the Brachypodium distachyon $(2 n=10)$, B. stacei $(2 n=20)$, and $B$. hybridum ( $2 n=30)$ lines derived from populations represented in the Universidad Politécnica de Madrid (UPM) collection (Iberian Peninsula and Balearic Islands) and in the National Centre of Plant Genetic Resources of Spain (CRF-INIA) collection (Canary Islands). The province code of sampled populations is indicated by one or two letters (see Table S1 for details).

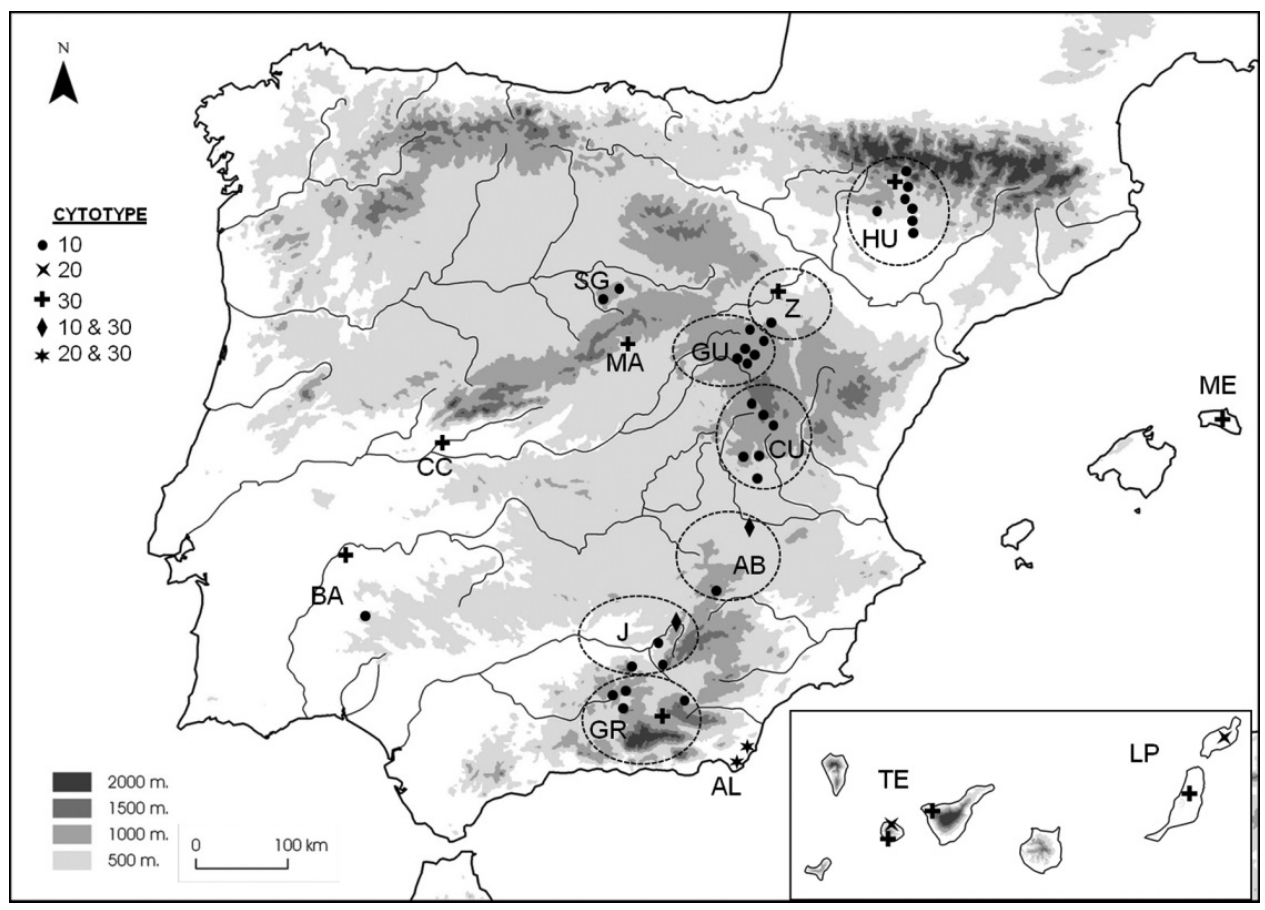

Table 1. Summary of the analysis of amplification profiles for ALB165, ALB311, BD330, and R2-3 SSR markers in the Brachypodium distachyon $(2 n=10)$, B. stacei $(2 n=20)$, and B. hybridum $(2 n=30)$ lines examined.

\begin{tabular}{|c|c|c|c|c|c|c|c|c|c|c|}
\hline & & & \multicolumn{8}{|c|}{ Marker amplification range } \\
\hline & & & \multicolumn{2}{|c|}{ ALB165 (Bd1) } & \multicolumn{2}{|c|}{ ALB311 (Bd5) } & \multicolumn{2}{|c|}{ BD330 (Bd2) } & \multicolumn{2}{|c|}{$\mathrm{R} 2-3(\mathrm{Bd} 3)$} \\
\hline & $2 n$ & $N^{*}$ & $137-141$ & $150-195$ & $223-227$ & 231 & 168 & $174-176$ & 189 & 191-204 \\
\hline B. distachyon & 10 & 65 & - & + & + & - & - & + & - & + \\
\hline B. stacei & 20 & 5 & + & - & - & + & + & - & + & - \\
\hline B. hybridum & 30 & 16 & + & + & + & + & + & + & + & + \\
\hline
\end{tabular}

Note: + , amplification band in the range; -, no amplification band in the range. The chromosomal location of each marker in the B. distachyon genome is noted in brackets.

*Including 78 UPM lines, 5 lines derived from CRF-INIA accessions, and the reference lines for each of the three species.

and R2-3 in the diploid species has resulted in a single amplification band, with no overlap between the allelic variation found in $2 n=10$ and $2 n=20$ lines, while two fragments have been detected in the allotetraploid $B$. hybridum $(2 n=$ 30 lines), one of each being in the respective size range of the B. distachyon and B. stacei alleles (Table 1; see Table S3 for detailed results). Therefore, these four SSR markers offer a valid PCR-based alternative to direct chromosome counts or flow cytometry for reliable cytotyping and subsequent taxonomic assignment within this complex of Brachypodium species.

Furthermore, the remarkable size difference found for ALB165 alleles between $2 n=10$ and $2 n=20$ lines $(150$ 195 bp vs. 137-139 bp, respectively) allows their discrimination in agarose gels: a unique band is observed in diploids, with distinct mobility for $B$. distachyon and B. stacei, whereas two bands are obtained for B. hybridum (Fig. 2). Thus this particular SSR marker provides a suitable tool for annual Brachypodium species identification. The analysis to
Fig. 2. Analysis of ALB165 SSR marker amplification in agarose gels. Lanes 1, 2, and 3 correspond to Brachypodium distachyon $(2 n=10)$ samples and lanes 4,5 , and 6 correspond to $B$. stace $i$ $(2 n=20)$ samples. In both cases a single amplification band is visible. Lanes 7, 8, and 9 correspond to B. hybridum $(2 n=30)$ samples. In this case, two distinct amplification fragments are clearly visible. The product sizes for these samples are given in Table S3. Lane $\mathrm{M}$ contains a 100-bp size marker.

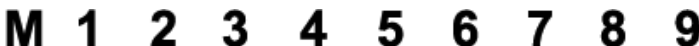

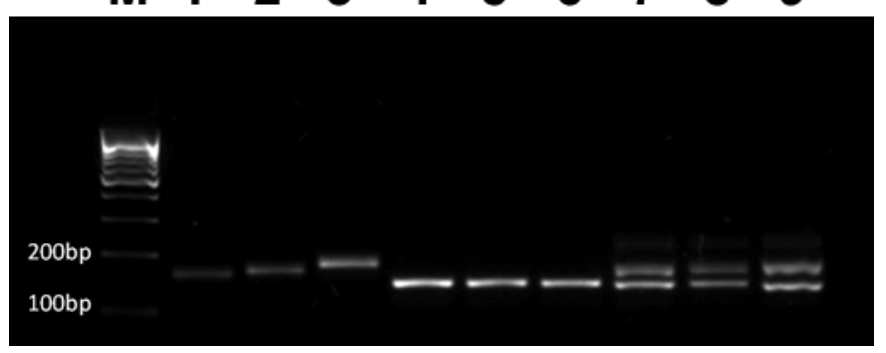


be conducted for cytotype assignation of a sample is not only easy and fast but also cheaper than other alternative methods, as fluorescent labeling and capillary electrophoresis of PCR amplification products is not required.

The allopolyploid origin of B. hybridum is currently out of debate mainly based upon the strong cytogenetic evidences reported by Hasterok and co-workers (Hasterok et al. 2004, 2006; Idziak et al. 2011). It has also been confirmed by the analysis of plastid and nuclear gene sequences (Catalán et al. 2012) and prolamin storage protein profiles (Hammami et al. 2011) on collections of $B$. distachyon (s.l.) including samples representative of the three cytotypes. Results in Table 1 provide additional support that $B$. hybridum derives from $B$. distachyon and the recently described $B$. stacei. The finding that 4 out of 15 SSR markers behave additively in the allotetraploid genotypes suggests that roughly $25 \%$ of the diploid genomes of $B$. distachyon and $B$. stacei remain intact after the polyploidization process. It is worthy of noting that each of the species-specific SSR markers is located on a different B. distachyon chromosome.

As microsatellite markers are co-dominant, the observation of a single amplification fragment in all diploid lines and two in the allotetraploids indicates full homocigosity for the surveyed loci in the genotypes examined. This agrees with the expected results from the self-breeding lifestyle of the annual Brachypodium species that in some cases (e.g., B. distachyon) is greatly imposed by cleistogamous flowers (Khan and Stace 1999). However, it cannot be totally excluded that cross pollination may have sporadically succeeded in these autogamous plants. In fact, heterozygotes have been reported at very low frequencies in Brachypodium collections examined by SSR markers (e.g., Bakker et al. 2009; Vogel et al. 2009). Nonetheless, the B. distachyon-type specimens genotyped as heterozygotes by Bakker et al. (2009) were $2 n=30$ (B. hybridum) plants, where two SSR amplification products could in fact reflect homozygous allotetraploid genotypes. The species-specific SSR markers described in this study can serve to confirm or discard the eventual existence of heterozygotes in Brachypodium samples. So, the nonoverlapping amplification fragment ranges in the diploid species genomes (Table 1) provides a tool to discern whether two bands generated in a given individual correspond to a heterozygous diploid genotype, of either B. distachyon or B. stacei, or to a homozygous genotype of $B$. hybridum. The whole set of markers should be checked in those samples where the amplification profile for one of them resulted inconclusive as heterozygosity for four unlinked SSR loci is highly unlikely to occur.

ALB165 shows the highest level of intra-cytotypic (i.e., intraspecific) allelic diversity among the four species-specific SSR markers (see detailed data as supplementary material in Table S3). Fourteen distinct ALB165 alleles have been detected in our collection of 64 Spanish lines of B. distachyon $(2 n=10)$, whereas the number of alleles scored at the remaining loci was as few as two or three. The level of diversity assessed with ALB165 marker in our collection (PIC = 0.8672; Table S2) was greater than that found in 187 samples of $B$. distachyon collected in Turkey (PIC $=0.5586$; Vogel et al. 2009). It is worthy of noting that the ALB165 allele found in the $B$. distachyon reference line $\mathrm{Bd} 21$ is the commonest in both collections as it is present in 119 out of 187 Turkish lines and 20 out of 64 Spanish lines (Table S3). Although the number of samples for the other two Brachypodium species under study is restricted, it is remarkable that ALB165 is the only polymorphic marker in the $B$. stace $i$ lines examined as well as the only marker for which a new fragment size, not detected in any of the diploids, has been found in the allotetraploid B. hybridum lines.

The set of $B$. hybridum lines examined, including the reference line ABR113, covers a wide area of the Iberian Peninsula as well as the Canary and Balearic Islands (Fig. 1), thus representing very distinct eco-climatic conditions. It is then likely that, despite small sized, it encompasses much of the genotypic variability of this species in the western Mediterranean. Our study suggests that $B$. hybridum shows a much lesser allelic variation than $B$. distachyon for marker ALB165. Thirteen out of the 16 hybridum lines genotyped are monomorphic in the amplification range shared with $B$. distachyon (PIC $=0.3281)$. Furthermore, 11 of the allotetraploid samples have identical ALB165 profiles (see Table S3). It is noticeable that, as stated earlier for B. distachyon, the commonest ALB165 profile in the collection of $B$. hybridum lines described here is the same as that detected in the reference-type of this species (line ABR113). For the remaining species-specific SSR markers, the amplification product within the $B$. staceii size range was invariably the unique allele present in the $2 n=20$ lines, while certain variation was obtained for fragments in the size range of $B$. distachyon. However, the commonest allele in the $2 n=30$ lines was not usually the most frequent in the $2 n=10$ lines. The disagreement is striking for ALB311, as the 223-bp fragment, amplified in the majority of the $B$. hybridum lines, is present in a unique one of the $65 \mathrm{~B}$. distachyon lines studied. To confirm whether these preliminary findings reflect the evolutionary history of the western Mediterranean accessions of the allotetraploid $B$. hybridum, enlarging the pool of molecularly characterized Brachypodium germplasm resources is required, especially concerning the rarest species B. stacei. Such a goal will surely be addressed soon as this species triangle is indeed attracting a great interest for polyploid origin and genome evolution studies (Bakker et al. 2009; Catalán et al. 2012; Manzaneda et al. 2012).

\section{Acknowledgements}

The authors thank I. Sevilla, G. Soria, and L. García-Toledano for helpful assistance. We are grateful to P. Catalán for providing seed samples of the reference lines included in the study. This work has been funded by grants AGL200909980 (Ministry of Science and Innovation, Spain) and CCG10-UPM/GEN-4980 (Comunidad de Madrid-UPM).

\section{References}

Bakker, E.G., Montgomery, B., Nguyen, T., Eide, K., Chang, J., Mockler, T.C., et al. 2009. Strong population structure characterizes weediness gene evolution in the invasive grass species Brachypodium distachyon. Mol. Ecol. 18(12): 2588-2601. doi:10. 1111/j.1365-294X.2009.04225.x. PMID:19457186.

Catalán, P., Müller, J., Hasterok, R., Jenkins, G., Mur, L.A.J., Langdon, T., et al. 2012. Evolution and taxonomic split of the model grass Brachypodium distachyon. Ann. Bot. (Lond.), 109(2): 385-405. doi:10.1093/aob/mcr294.

Draper, J., Mur, L.A.J., Jenkins, G., Ghosh-Biswas, G.C., Bablak, P., 
Hasterok, R., and Routledge, A.P.M. 2001. Brachypodium distachyon. A new model system for functional genomics in grasses. Plant Physiol. 127(4): 1539-1555. doi:10.1104/pp. 010196. PMID:11743099.

Filiz, E., Ozdemir, B.S., Budak, F., Vogel, J.P., Tuna, M., and Budak, H. 2009. Molecular, morphological, and cytological analysis of diverse Brachypodium distachyon inbred lines. Genome, 52(10): 876-890. doi:10.1139/G09-062. PMID:19935911.

Garvin, D.F., Gu, Y.-Q., Hasterok, R., Hazen, S.P., Jenkins, G., Mockler, T.C., et al. 2008. Development of genetic and genomic research resources for Brachypodium distachyon, a new model system for grass crop research. Crop Sci. 48(Suppl. 1): S69-S84. doi:10.2135/cropsci2007.06.0332tpg.

Hammami, R., Jouve, N., Cuadrado, A., Soler, C., and Gonzalez, J.M. 2011. Prolamin storage proteins and alloploidy in wild populations of the small grass Brachypodium distachyon (L.) P. Beauv. Plant Syst. Evol. 297(1-2): 99-111. doi:10.1007/s00606011-0502-7.

Hasterok, R., Draper, J., and Jenkins, G. 2004. Laying the cytotaxonomic foundations of a new model grass, Brachypodium distachyon (L.) Beauv. Chromosome Res. 12(4): 397-403. doi:10. 1023/B:CHRO.0000034130.35983.99. PMID:15241018.

Hasterok, R., Marasek, A., Donnison, I.S., Armstead, I., Thomas, A., King, I.P., et al. 2006. Alignment of the genomes of Brachypodium distachyon and temperate cereals and grasses using bacterial artificial chromosome landing with fluorescence in situ hybridization. Genetics, 173(1): 349-362. doi:10.1534/genetics.105. 049726. PMID:16489232.
Idziak, D., Betekhtin, A., Wolny, E., Lesniewska, K., Wright, J., Febrer, M., et al. 2011. Painting the chromosomes of Brachypodium - current status and future prospects. Chromosoma, 120(5): 469-479. doi:10.1007/s00412-011-0326-9. PMID:21667205.

Khan, M.A., and Stace, C.A. 1999. Breeding relationships in the genus Brachypodium (Poaceae: Pooideae). Nord. J. Bot. 19(3): 257-269. doi:10.1111/j.1756-1051.1999.tb01108.x.

Manzaneda, A.J., Rey, P.J., Bastida, J.M., Weiss-Lehman, C., Raskin, E., and Mitchell-Olds, T. 2012. Environmental aridity is associated with cytotype segregation and polyploidy occurrence in Brachypodium distachyon (Poaceae). New Phytol. 193(3): 797-805. doi:10.1111/j.1469-8137.2011.03988.x. PMID:22150799.

Mur, L.A.J., Allainguillaume, J., Catalán, P., Hasterok, R., Jenkins, G., Lesniewska, K., et al. 2011. Exploiting the Brachypodium Tool Box in cereal and grass research. New Phytol. 191(2): 334-347. doi:10.1111/j.1469-8137.2011.03748.x. PMID:21623796.

Ozdemir, B.S., Hernandez, P., Filiz, E., and Budak, H. 2008. Brachypodium genomics. Int. J. Plant Genomics, 2008: 536104. PMID:18309367.

Robertson, I.H. 1981. Chromosome numbers in Brachypodium Beauv. (Gramineae). Genetica, 56(1): 55-60. doi:10.1007/ BF00126930.

Vain, P. 2011. Brachypodium as a model system for grass research. J. Cereal Sci. 54(1): 1-7. doi:10.1016/j.jcs.2011.04.002.

Vogel, J.P., Tuna, M., Budak, H., Huo, N., Gu, Y.Q., and Steinwand, M.A. 2009. Development of SSR markers and analysis of diversity in Turkish populations of Brachypodium distachyon. BMC Plant Biol. 9: 88. doi:10.1186/1471-2229-9-88. PMID:19594938. 
TABLE S1.

Geographical details of the Spanish locations represented in the UPM and CRF-INIA Brachypodium collections. Each population is coded by one or two letters (province code) plus a number (location within a province). For populations from the CRF-INIA collection, the catalogue number (NC) is also indicated.

\begin{tabular}{|c|c|c|c|c|c|c|c|}
\hline Collection & Poulation code & Province & Location & $2 n^{*}$ & Latitude & Longitude & Alt (m) \\
\hline \multirow{24}{*}{\begin{tabular}{|l|} 
UPM \\
\end{tabular}} & AB1 & Albacete & Riopar & 10 & $38^{\circ} 27^{\prime} 40^{\prime \prime} \mathrm{N}$ & $2^{\circ} 27^{\prime} 55^{\prime \prime} \mathrm{W}$ & 1117 \\
\hline & AB3 & Albacete & La Gineta & $10+30$ & $39^{\circ} 10^{\prime} 33^{\prime \prime} \mathrm{N}$ & $1^{\circ} 57^{\prime} 57^{\prime \prime} \mathrm{W}$ & 658 \\
\hline & AL1 & Almería & Cala Chica & $20+30$ & $36^{\circ} 43^{\prime} 57^{\prime \prime} \mathrm{N}$ & $2^{\circ} 07^{\prime} 59^{\prime \prime} \mathrm{W}$ & 60 \\
\hline & AL5 & Almería & San José & $20+30$ & $36^{\circ} 46^{\prime} 00^{\prime \prime} \mathrm{N}$ & $2^{\circ} 06^{\prime} 23^{\prime \prime} \mathrm{W}$ & 10 \\
\hline & BA3 & Badajoz & Badajoz & 30 & $38^{\circ} 53^{\prime} 16^{\prime \prime} \mathrm{N}$ & $6^{\circ} 54^{\prime} 47^{\prime \prime} \mathrm{W}$ & 195 \\
\hline & BA6 & Badajoz & Fregenal de la Sierra & 10 & $38^{\circ} 10^{\prime} 10^{\prime \prime} \mathrm{N}$ & $6^{\circ} 39^{\prime} 43^{\prime \prime} \mathrm{W}$ & 608 \\
\hline & CC3 & Cáceres & Almaraz & 30 & $39^{\circ} 48^{\prime} 16^{\prime \prime} N$ & $5^{\circ} 41^{\prime} 11^{\prime \prime} \mathrm{W}$ & 277 \\
\hline & CU1 & Cuenca & Gabaldón & 10 & $39^{\circ} 38^{\prime} 10^{\prime \prime} \mathrm{N}$ & $1^{0} 56^{\prime} 16^{\prime \prime} \mathrm{W}$ & 924 \\
\hline & CU2 & Cuenca & Pass of Tordiga & 10 & $39^{\circ} 55^{\prime} 06^{\prime \prime} \mathrm{N}$ & $2^{\circ} 03^{\prime} 38^{\prime \prime} \mathrm{W}$ & 1193 \\
\hline & CU3 & Cuenca & Pass of Rocho & 10 & $39^{\circ} 55^{\prime} 48^{\prime \prime} \mathrm{N}$ & $1^{\circ} 56^{\prime} 05^{\prime \prime} \mathrm{W}$ & 1077 \\
\hline & CU4 & Cuenca & Huerta del Marquesado & 10 & $40^{\circ} 10^{\prime} 14^{\prime \prime} \mathrm{N}$ & $1^{\circ} 40^{\prime} 22^{\prime \prime} \mathrm{W}$ & 1295 \\
\hline & CU5 & Cuenca & Mountain range of Cuenca & 10 & $40^{\circ} 12^{\prime} 18^{\prime \prime} \mathrm{N}$ & $1^{\circ} 41^{\prime} 31^{\prime \prime} \mathrm{W}$ & 1525 \\
\hline & CU6 & Cuenca & Source of Cuervo river & 10 & $40^{\circ} 25^{\prime} 42^{\prime \prime} \mathrm{N}$ & $1^{0} 53^{\prime} 54^{\prime \prime} \mathrm{W}$ & 1429 \\
\hline & GR1 & Granada & Pass of Onitar & 10 & $37^{\circ} 27^{\prime} 04^{\prime \prime} \mathrm{N}$ & $3^{\circ} 36^{\prime} 57^{\prime \prime} \mathrm{W}$ & 935 \\
\hline & GR2 & Granada & Pass of Zegri & 10 & $37^{\circ} 25^{\prime} 22^{\prime \prime} \mathrm{N}$ & $3^{\circ} 35^{\prime} 52^{\prime \prime} \mathrm{W}$ & 1079 \\
\hline & GR3 & Granada & Iznalloz & 10 & $37^{\circ} 24^{\prime} 02 " \mathrm{~N}$ & $3^{\circ} 28^{\prime} 35^{\prime \prime} \mathrm{W}$ & 925 \\
\hline & GR5 & Granada & Gor & 30 & $37^{\circ} 22^{\prime} 00^{\prime \prime} \mathrm{N}$ & $2^{\circ} 57^{\prime} 54^{\prime \prime} \mathrm{W}$ & 1340 \\
\hline & GR6 & Granada & National Park 'Sierra de Baza' & 10 & $37^{\circ} 26^{\prime} 22^{\prime \prime} \mathrm{N}$ & $2^{\circ} 53^{\prime} 25^{\prime \prime} \mathrm{W}$ & 1194 \\
\hline & GU1 & Guadalajara & Prados Redondos & 10 & $40^{\circ} 48^{\prime} 44^{\prime \prime} \mathrm{N}$ & $1^{\circ} 48^{\prime} 30^{\prime \prime} \mathrm{W}$ & 1138 \\
\hline & GU2 & Guadalajara & Molina de Aragón & 10 & $40^{\circ} 51^{\prime} 18^{\prime \prime} \mathrm{N}$ & $1^{\circ} 52^{\prime} 14^{\prime \prime} \mathrm{W}$ & 1120 \\
\hline & GU3 & Guadalajara & Embid & 10 & $40^{\circ} 58^{\prime} 14^{\prime \prime} \mathrm{N}$ & $1^{\circ} 42^{\prime} 54^{\prime \prime} \mathrm{W}$ & 1084 \\
\hline & GU4 & Guadalajara & Cerro Pelado & 10 & $40^{\circ} 48^{\prime} 44^{\prime \prime} \mathrm{N}$ & $1^{\circ} 55^{\prime} 18^{\prime \prime} \mathrm{W}$ & 1177 \\
\hline & GU5 & Guadalajara & Valsalobre & 10 & $40^{\circ} 49^{\prime} 06^{\prime \prime} \mathrm{N}$ & $1^{0} 54^{\prime} 24^{\prime \prime} \mathrm{W}$ & 1122 \\
\hline & GU6 & Guadalajara & Cubillejo de la Sierra & 10 & $40^{\circ} 51^{\prime} 49^{\prime \prime} \mathrm{N}$ & $1^{\circ} 51^{\prime} 04^{\prime \prime} \mathrm{W}$ & 1203 \\
\hline
\end{tabular}




\begin{tabular}{|c|c|c|c|c|c|c|c|}
\hline & HU1 & Huesca & Almunia de San Juan & 10 & $41^{\circ} 56^{\prime} 25^{\prime \prime} \mathrm{N}$ & $0^{\circ} 15^{\prime} 55^{\prime \prime} \mathrm{E}$ & 427 \\
\hline & HU2 & Huesca & Monte Palau & 10 & $42^{\circ} 01^{\prime} 49^{\prime \prime} \mathrm{N}$ & $0^{\circ} 16^{\prime} 30^{\prime \prime} \mathrm{E}$ & 521 \\
\hline & HU3 & Huesca & El Grado & 10 & $42^{\circ} 07^{\prime} 51^{\prime \prime} \mathrm{N}$ & $0^{\circ} 13^{\prime} 34 " \mathrm{E}$ & 357 \\
\hline & HU4 & Huesca & Mirador de Mipanas & 10 & $42^{\circ} 12^{\prime} 12^{\prime \prime} \mathrm{N}$ & $0^{\circ} 12^{\prime} 44^{\prime \prime} \mathrm{E}$ & 544 \\
\hline & HU5 & Huesca & Escanilla & 10 & $42^{\circ} 16^{\prime} 51^{\prime \prime} \mathrm{N}$ & $0^{\circ} 11^{\prime} 46^{\prime \prime} \mathrm{E}$ & 463 \\
\hline & HU6 & Huesca & Morillo de Tou & 30 & $42^{\circ} 22^{\prime} 30^{\prime \prime} \mathrm{N}$ & $0^{\circ} 09^{\prime} 13^{\prime \prime} \mathrm{E}$ & 516 \\
\hline & HU7 & Huesca & Escalona & 10 & $42^{\circ} 29^{\prime} 53^{\prime \prime} \mathrm{N}$ & $0^{\circ} 08^{\prime} 44^{\prime \prime} \mathrm{E}$ & 576 \\
\hline & HU9 & Huesca & Nueno & 10 & $42^{\circ} 17^{\prime} 05^{\prime \prime} \mathrm{N}$ & $0^{\circ} 25^{\prime} 29^{\prime \prime} \mathrm{W}$ & 826 \\
\hline & $\mathrm{J3}$ & Jaén & Mata-Bejid & 10 & $37^{\circ} 41^{\prime} 18^{\prime \prime} \mathrm{N}$ & $3^{\circ} 29^{\prime} 31^{\prime \prime} \mathrm{W}$ & 1065 \\
\hline & 34 & Jaén & Pass of Tiscar & 10 & $37^{\circ} 47^{\prime} 12^{\prime \prime} \mathrm{N}$ & $3^{\circ} 02^{\prime} 20^{\prime \prime} \mathrm{W}$ & 1154 \\
\hline & 36 & Jaén & National Park 'Sierra de Segura' & 10 & $38^{\circ} 01^{\prime} 59^{\prime \prime} \mathrm{N}$ & $2^{\circ} 51^{\prime} 57^{\prime \prime} \mathrm{W}$ & 677 \\
\hline & 37 & Jaén & El Tranco & $10+30$ & $38^{\circ} 07^{\prime} 23^{\prime \prime} \mathrm{N}$ & $2^{\circ} 47^{\prime} 47^{\prime \prime} \mathrm{W}$ & 687 \\
\hline & MA1 & Madrid & Patones & 30 & $40^{\circ} 53^{\prime} 17^{\prime \prime} \mathrm{N}$ & $3^{\circ} 26^{\prime} 59^{\prime \prime} \mathrm{W}$ & 837 \\
\hline & ME1 & Mallorca & Mahón (Island of Menorca) & 30 & $39^{\circ} 53^{\prime} 41^{\prime \prime} \mathrm{N}$ & $4^{\circ} 16^{\prime} 13^{\prime \prime} \mathrm{E}$ & 37 \\
\hline & SG1 & Segovia & Moral de Hornuez & 10 & $41^{\circ} 27^{\prime} 56^{\prime \prime} \mathrm{N}$ & $3^{\circ} 36^{\prime} 39^{\prime \prime} \mathrm{W}$ & 1109 \\
\hline & SG2 & Segovia & Carabias & 10 & $41^{\circ} 26^{\prime} 12^{\prime \prime} \mathrm{N}$ & $3^{\circ} 40^{\prime} 00^{\prime \prime} \mathrm{W}$ & 1157 \\
\hline & Z2 & Zaragoza & Puerto Cavero & 30 & $41^{\circ} 23^{\prime} 32^{\prime \prime} N$ & $1^{\circ} 33^{\prime} 55^{\prime \prime} \mathrm{W}$ & 771 \\
\hline & $Z 3$ & Zaragoza & Torralba de los Frailes & 10 & $40^{\circ} 58^{\prime} 13^{\prime \prime} \mathrm{N}$ & $1^{\circ} 39^{\prime} 28^{\prime \prime} \mathrm{W}$ & 1134 \\
\hline CRF-INIA & LP2 (NC050401) & Las Palmas & Betancuria (Island of Fuerteventura) & 30 & $28^{\circ} 25^{\prime} N$ & $14^{\circ} 03^{\prime} \mathrm{W}$ & 396 \\
\hline & LP6 (NC050440) & Las Palmas & Teguise (Island of Lanzarote) & 20 & $29^{\circ} 04^{\prime} \mathrm{N}$ & $13^{\circ} 31^{\prime} \mathrm{W}$ & 283 \\
\hline & TE1 (NC050335) & Tenerife & Buenavista N (Island of Tenerife) & 30 & $28^{\circ} 21^{\prime} \mathrm{N}$ & $16^{\circ} 51^{\prime} \mathrm{W}$ & 499 \\
\hline & TE4 (NC050363) & Tenerife & Agulo (Island of Gomera) & 20 & $28^{\circ} 11^{\prime} \mathrm{N}$ & $17^{\circ} 11^{\prime} \mathrm{W}$ & 202 \\
\hline & TE5 (NC050368) & Tenerife & Vallehermoso (Island of Gomera) & 30 & $28^{\circ} 11^{\prime} \mathrm{N}$ & $17^{0} 14^{\prime} \mathrm{W}$ & 456 \\
\hline
\end{tabular}

*: Cytotype of derived lines that have been used in this study.

Alt: Altitude above sea level. 


\section{TABLE S2.}

Description of Brachypodium molecular marker loci used in this study. Chromosomal location, amplification range, and polymorphism data are referred to $B$. distachyon $(2 n=10)$ lines.

\begin{tabular}{|c|c|c|c|c|c|c|c|c|c|}
\hline $\begin{array}{l}\text { Marker } \\
\text { locus }\end{array}$ & $\begin{array}{l}\text { Repeat } \\
\text { unit }\end{array}$ & Forward Primer & Reverse Primer & $\begin{array}{l}\text { Chromosomal } \\
\text { location }\end{array}$ & $\begin{array}{l}\text { Amplification } \\
\text { range (bp) }\end{array}$ & $\begin{array}{l}\text { No. of } \\
\text { Alleles }\end{array}$ & $\begin{array}{l}\text { Major Alele } \\
\text { Frequency }\end{array}$ & $\begin{array}{l}\text { Gene } \\
\text { Diversity }\end{array}$ & Heterozygosity \\
\hline ALB165 & ata & TTCGTGGTTCAACAACATGG & ATTTGCCCCACAAATGGTTA & Bd1: $35,998,570$ & 150-195 & 14 & 0.2812 & 0.8672 & 0 \\
\hline ALB311 & ga & CCTAACAGCTTCCGTCTCCA & CGTCGTCTTCAGGTCTTTCC & Bd5: 18,580,928 & $223-227$ & 3 & 0.6094 & 0.4878 & 0 \\
\hline BdSSR330 & ND & GTCTCCTCGGGATCCAACTT & СCTTCCCCGTCTTCTCTTCT & Bd2: 52,344,096 & $174-176$ & 2 & 0.7969 & 0.3237 & 0 \\
\hline R2-3-AB & ND & TCCGGATCTCGATCTCAAAC & CGTCGACAAGCTCAAGAAGC & Bd3: 59,072,368 & $191-204$ & 4 & 0.6406 & 0.4818 & 0 \\
\hline
\end{tabular}


TABLE S3.

SSR profiles in the Brachypodium lines examined. Distinct lines derived from the same population are named by different numbers following the population code. The catalogue number (NC) of lines established from CRF-INIA accessions is noted in brackets. For the lines whose ALB165-SSR amplification products have been analyzed in agarose gels, the corresponding lane in Figure 2 is noted.

\begin{tabular}{|c|c|c|c|c|c|}
\hline \multirow[b]{2}{*}{ cytotype } & \multirow[b]{2}{*}{ line } & \multicolumn{4}{|l|}{ SSR marker } \\
\hline & & ALB165 & ALB311 & BdSSR330 & R2-3-ABI \\
\hline & $\mathrm{Bd} 21$ & 157 & 223 & 176 & 204 \\
\hline \multirow[t]{39}{*}{$2 n=10$} & BdUPM_AB1.2 & 174 & 225 & 174 & 191 \\
\hline & BdUPM_AB1.4 & 177 & 225 & 176 & 202 \\
\hline & BdUPM_AB3.3 & 171 [3] & 225 & 176 & 204 \\
\hline & BdUPM_AB3.5 & 163 & 225 & 174 & 204 \\
\hline & BdUPM_BA6.4 & 186 & 227 & 176 & 202 \\
\hline & BdUPM_BA6.6 & 160 & 227 & 174 & 204 \\
\hline & BdUPM_CU1.4 & 186 & 227 & 174 & 204 \\
\hline & BdUPM_CU1.6 & 150 & 227 & 174 & 202 \\
\hline & BdUPM_CU2.2 & 183 & 225 & 174 & 204 \\
\hline & BdUPM_CU2.6 & 157 & 227 & 174 & 204 \\
\hline & BdUPM_CU3.5 & 166 & 227 & 174 & 204 \\
\hline & BdUPM_CU3.6 & 160 & 227 & 174 & 204 \\
\hline & BdUPM_CU4.3 & 157 & 225 & 174 & 202 \\
\hline & BdUPM_CU4.6 & 163 & 227 & 174 & 204 \\
\hline & BdUPM_CU5.3 & 157 & 225 & 174 & 204 \\
\hline & BdUPM_CU5.5 & 166 & 225 & 174 & 204 \\
\hline & BdUPM_CU6.1 & 157 & 227 & 174 & 204 \\
\hline & BdUPM_CU6.4 & 183 & 227 & 174 & 204 \\
\hline & BdUPM_GR1.4 & 195 & 225 & 176 & 204 \\
\hline & BdUPM_GR1.5 & 160 [2] & 227 & 176 & 202 \\
\hline & BdUPM_GR2.1 & 166 & 225 & 176 & 202 \\
\hline & BdUPM_GR2.6 & 180 & 225 & 176 & 204 \\
\hline & BdUPM_GR3.4 & 174 & 227 & 174 & 204 \\
\hline & BdUPM_GR3.6 & 180 & 225 & 176 & 202 \\
\hline & BdUPM_GR6.3 & 150 & 227 & 174 & 202 \\
\hline & BdUPM_GR6.4 & 153 & 223 & 174 & 202 \\
\hline & BdUPM_GU1.5 & 157 & 225 & 174 & 204 \\
\hline & BdUPM_GU1.6 & 174 & 225 & 176 & 204 \\
\hline & BdUPM_GU2.1 & 153 & 225 & 176 & 204 \\
\hline & BdUPM_GU2.4 & 157 & 225 & 176 & 204 \\
\hline & BdUPM_GU3.1 & 157 & 225 & 174 & 204 \\
\hline & BdUPM_GU3.5 & 157 & 225 & 174 & 204 \\
\hline & BdUPM_GU4.3 & 157 & 225 & 174 & 204 \\
\hline & BdUPM_GU4.5 & 166 & 225 & 174 & 204 \\
\hline & BdUPM_GU5.1 & 157 & 225 & 174 & 204 \\
\hline & BdUPM_GU5.6 & 171 & 225 & 174 & 204 \\
\hline & BdUPM_GU6.1 & 153 & 227 & 174 & 204 \\
\hline & BdUPM_HU1.5 & 153 & 227 & 174 & 204 \\
\hline & BdUPM_HU1.6 & 157 & 227 & 174 & 204 \\
\hline
\end{tabular}




\begin{tabular}{|c|c|c|c|c|c|c|c|c|c|c|}
\hline & BdUPM_HU2.1 & & 160 & & 225 & & & 174 & & 204 \\
\hline & BdUPM_HU2.5 & & 163 & & 225 & & & 174 & & 202 \\
\hline & BdUPM_HU3.4 & & 174 & & 225 & & & 174 & & 204 \\
\hline & BdUPM_HU3.5 & & 160 & & 227 & & & 174 & & 202 \\
\hline & BdUPM_HU4.5 & & 186 & & 227 & & & 174 & & 202 \\
\hline & BdUPM_HU4.6 & & 160 & & 227 & & & 174 & & 202 \\
\hline & BdUPM_HU5.5 & & 157 & & 227 & & & 174 & & 204 \\
\hline & BdUPM_HU7.1 & & 168 & & 227 & & & 174 & & 202 \\
\hline & BdUPM_HU7.6 & & 166 & & 225 & & & 174 & & 204 \\
\hline & BdUPM_HU9.1 & & 157 & & 225 & & & 174 & & 204 \\
\hline & BdUPM_HU9.2 & & 157 & & 225 & & & 174 & & 200 \\
\hline & BdUPM_J3.3 & & 163 & & 225 & & & 174 & & 202 \\
\hline & BdUPM_J3.6 & & 186 & & 225 & & & 174 & & 204 \\
\hline & BdUPM_J4.2 & & 157 & & 225 & & & 176 & & 204 \\
\hline & BdUPM_J4.3 & & 171 & & 225 & & & 174 & & 202 \\
\hline & BdUPM_J6.2 & & 174 & & 225 & & & 174 & & 202 \\
\hline & BdUPM_J6.5 & & 174 & & 225 & & & 174 & & 204 \\
\hline & BdUPM_J7.2 & & 174 & & 227 & & & 176 & & 202 \\
\hline & BdUPM_J7.6 & & 183 & & 225 & & & 174 & & 204 \\
\hline & BdUPM_SG1.2 & & 153 & & 225 & & & 174 & & 202 \\
\hline & BdUPM_SG1.5 & & 153 & & 225 & & & 174 & & 202 \\
\hline & BdUPM_SG2.1 & & 157 & [1] & 225 & & & 174 & & 204 \\
\hline & BdUPM_SG2.3 & & 157 & & 225 & & & 174 & & 204 \\
\hline & BdUPM_Z3.2 & & 157 & & 227 & & & 174 & & 204 \\
\hline & BdUPM_Z3.6 & & 160 & & 227 & & & 174 & & 202 \\
\hline $2 n=20$ & BsUPM_AL1.1 & 137 & & & & 231 & 168 & & 189 & \\
\hline & BsUPM_AL5.2 & 139 & & [4] & & 231 & 168 & & 189 & \\
\hline & LP6.1 (NC050440)* & 137 & & [5] & & 231 & 168 & & 189 & \\
\hline & TE4.3 (NC050363)* & 139 & & [6] & & 231 & 168 & & 189 & \\
\hline $2 n=30$ & BhUPM_AB3.7 & 137 & 163 & & 223 & 231 & 168 & 174 & 189 & 202 \\
\hline & BhUPM_AL1.2 & 141 & 163 & & 225 & 231 & 168 & 174 & 189 & 202 \\
\hline & BhUPM_AL5.3 & 137 & 163 & & 223 & 231 & 168 & 176 & 189 & 202 \\
\hline & BhUPM_BA3.2 & 137 & 157 & & 225 & 231 & 168 & 174 & 189 & 202 \\
\hline & BhUPM_CC3.2 & 137 & 163 & & 223 & 231 & 168 & 174 & 189 & 202 \\
\hline & BhUPM_GR5.1 & 137 & 163 & & 223 & 231 & 168 & 176 & 189 & 202 \\
\hline & BhUPM_HU6.2 & 137 & 163 & & 223 & 231 & 168 & 174 & 189 & 202 \\
\hline & BhUPM_J7.1 & 139 & 163 & & 223 & 231 & 168 & 176 & 189 & 204 \\
\hline & BhUPM_J7.5 & 137 & 163 & & 223 & 231 & 168 & 174 & 189 & 204 \\
\hline & BhUPM_MA1.2 & 137 & 171 & [9] & 227 & 231 & 168 & 174 & 189 & 202 \\
\hline & BhUPM_ME1.1 & 137 & 166 & [8] & 223 & 231 & 168 & 174 & 189 & 202 \\
\hline & BhUPM_Z2.2 & 137 & 163 & & 227 & 231 & 168 & 174 & 189 & 202 \\
\hline & LP2.1 (NC050401)* & 137 & 163 & & 223 & 231 & 168 & 176 & 189 & 202 \\
\hline & TE1.1 (NC050335)* & 137 & 163 & [7] & 223 & 231 & 168 & 176 & 189 & 202 \\
\hline & TE5.1 (NC050368)* & 137 & 163 & & 223 & 231 & 168 & 176 & 189 & 202 \\
\hline
\end{tabular}

